\title{
Principals Profiles about Distributed Leadership: A Descriptive Study through Analysis of Multiple Correspondences of the Elementary Schools from Madrid, Spain
}

Ingrid del Valle Garcia Carreño ${ }^{1, *}$, Luis Vicente Amador Muñoz ${ }^{1} \&$ Macarena Esteban Ibañez ${ }^{1}$

${ }^{1}$ University Pablo Olavide, Sevilla. Spain

*Correspondence: University Pablo Olavide, Sevilla. Spain. E-mail: ivgarcar@alu.upo.es

*Grupo de investigación en acción socioeducativa (GIAS) (HUM 929). Director: Prof. D. Luis Vicente Amador Muñoz. Facultad de Ciencias Sociales; Dpto. Ciencias Sociales.

Received: February 6, 2018 Accepted: April 11, 2018 Published: May 8, 2018

doi:10.5296/ije.v10i2.12619 URL: https://doi.org/10.5296/ije.v10i2.12619

\begin{abstract}
Within the emerging leaderships there is no doubt that distributed leadership (DL) is a relevant concept for culture of the educational sector. DL is understood as a form of shared leadership that is based on a more collective and inclusive philosophy of traditional leadership theory that focuses on the skills, traits and behaviours of the leading individuals. The objective of this communication is to determine the DL profiles of the directors of some primary schools in Madrid. Method. Descriptive study through analysis of multiple correspondences and SPAD, with the questionnaire validated ad hoc practices of distributed leadership. The exhibition comprises a total of 23 schools (16 Public schools and 7 colleges) and 13 principals and 10 directors. In the community of Madrid Capital, Spain. Results. The profiles of the leaders found are eight, product of factors 1 and 2 (formal leader, innovator, Bureaucrat, organizational poietic) and factors 2 and 3 (instructional, training, empowerment, collaborative). Discussion. The profiles in this case can generate the self-knowledge of directives strengths and weaknesses, which arise as key conditions to initiate the practice of DL. It goes towards the assertive distribution of power, from the organization of the centre, from the traditional to the bureaucratic.
\end{abstract}

Keywords: school principal, profiles, distributed leadership, educational leadership, multivariate analysis of main components, madrid primary schools 


\section{Introduction}

The interest of studying the distributed leadership style, is becoming increasingly important, the predominant position in contemporary literature regarding distributed leadership (DL), establishes the following fundamental theories: The Theory of activity (Spillane et al., 2004); The theory of "substitutes for Leadership" (Jermier and Kerr, 1997); Theories on located and distributed cognition (Brown and Duguid, 1991; Gronn, 2002, 2008); The institutional theory (Ogawa and Bossert, 1995) and; The theory of Motivation (Bandura, 1989 and Locke, 2003) (Mentioned by García, 2017). The perspective of distribution, focuses on how the practice of leadership is distributed among the formal and informal leaders and in the analysed construct is a new leadership based on morals, centred on values, which by nature promotes its own Socialization, its distribution in the whole. In theoretical terms, DL corresponds to the means of multiple sources of guidance and direction, following the contours of experience in an organization, made coherent through a common culture.

This research arises in the first place, following the relevance of the DL phenomenon in improving the effectiveness of primary schools and secondly, in order to enrich the studies related to the primary centres in Madrid. The objective of this article is to present the results obtained, in relation to the perception of the Principals, with respect to the PDL dimension according to the selected primary schools. To this end, research has been designed using a quantitative methodology with a descriptive cut, in order to identify how the actors, value the DL process. To achieve these objectives an ad hoc questionnaire has been applied, in 25 public and concerted schools in Madrid, Capital.

\section{An Approximation to the Concept and Problem of Distributed Leadership}

At present there are many definitions and interpretations of the DL, but few are clear and the definitions that exist seem to differ from one another, such is the case of the area of organizational restructuring, there focuses much of the research, on DL's conceptions, as horizontal, organic and multifunctional structures replace hierarchical structures (Day, 2017). Evidence from different types of educational institutions confirms the idea that some leadership practices are valuable, in almost all contexts (Leithwood, 2009). For Spillane \& Diamond, J. (2007) and Spillane (2017) there is a perspective of DL, which recognizes the existence of several leaders and as explained by Harris (2004), the activities are widely shared within and between the organizations.

The characteristics of the distribution model in the first place focus primarily on interactions, rather than actions, supervisors and informal leadership roles. Secondly, it is the direction and influence in leadership, as well as the improvement of the organization's instruction (Spillane, 2017), recognizes the work of all people rather than contributing to the practice of leadership, if not formally designated or defined as the leaders. Third, the DL is also fundamental to the reconfiguration of the system and organization, as well as the redesign that requires horizontal decision making (Hargreaves, 2002). This model leads to a leadership perspective, as a phenomenon involving the organization as a whole. 
DL is considered multidimensional, with overlapping concepts of other leaderships (Woods, 2004, 2016). The combination of these terminologies has led the DL to have several meanings. The term DL is a powerful magnet for professionals, policy-makers and researchers. This is because it seems to be an apparent solution to the intensification of the Labour administration, as well as having inherent democratic and moral assumptions accompanied by notions of fair and democratic distribution.

About history of DL one of the first scholars to mention DL, is Gibb (1954), who defines it as an activity, whose functions are developed by the groups as a whole. Bolden (2011) mention the most protruding investigations of Gronn (2002, 2008) and Harris (2004). First, Gronn (2008) highlights the importance of the theories and research of authors such as: Mary Parker Follett (1942/2003) related to reciprocal influence; Gibb's (1954) works on leadership; French and Snyder (1959) and Dahl (1961) in the distribution of power and influence; Becker and Useem (1942) and Etzioni (1965) work with dual leadership; Kerr and Jermier (1978) on the substitutes for leadership; Katz and Kahn $(1966,1978)$ in shared leadership; Schein (1988) On leadership roles.

Second, Harris (2014) supports the research with the contributions of: Festinger et al. (1950) and Heinicke and Bales (1953) on the informal leadership of groups and teams; Barnard (1968) on the functions of the Executive and informal organization; The social learning theory of Manz and Sims (1993); The work of Hutchins (1995) on distributed cognition; Louis and Marks (1998) Professional Learning communities; Wheatley (1994) Work on complexity and systems. Leithwood (2009) emphasize the importance of organizational learning theory (Weick and Roberts, 1993, Salomon, 1993, Jermier and Kerr, 1997, Perkins, 1993).

For Bennett et al., (2003) DL appears at the end of 1990; it is there when the definition of DL actually arises. Harris (2013) points out that the definition and understanding of DL fluctuate between the normative and the theoretical, hence the literature supporting the definition of DL remains diverse and broad-based.

Despite these solid investigations, it is during the last decades, which has emerged in the educational research, the approach on the DL (Gronn, 2002 and Spillane, 2005), must be highlighted, that this new position, has been driven by a change of Paradigm, which moves the individual leader, by the leader or distributed leaders, being the main cause the demands in the educational leaders and in the world of the Education (Gronn, 2002 and Hulpia et al., 2009). For Elmore (2008) the important thing is instruction, improvement and school performance. Spillane (2006) and Spillane and Diamond (2007), have based the study, to a large extent, on distributed cognition to generate a theory of DL.

The DL of the school centre is one of the most vibrant elements, with which schools have to be effective and achieve quality results, school leaders are able to influence and shape the conditions in which they occur (Leithwood, 2009). The Principals' performance has been changing, today, the director must find the harmony between the pressures of the outside, economic crisis, ranking, academic results and the problems of the educational community, where the school is located. The review of the investigations affirms that to achieve, the 
improvement of the learning the performance of the directors must have traits of a model of up-down rather than bottom-up (Shatzer et al., 2014), however, it should be taken into account that although it is Recognize that a top-down authority model can be more effective for improving student learning outcomes.

The problem approach on school leadership, makes a difference in schools, is one of the most influential factors in student academic achievement and accounts for $25 \%$ of all school effects (Leithwood, 2009). It means that if the Principals exert the educational leadership they can influence the work of the teachers and improve in this way, the conditions in the development of the processes of teaching and of learning. The importance of the school management, as the performance of the management teams has evolved over time and is currently aiming, to the balance between all the members of the school community and to the constant improvement in the academic results (Knapp et al., 2014 and Spillane, 2017). The attitude of the person who assumes the functions of management in the school, is a key element that determines the success of processes of change in the institution, as well as for the development of the institutions (Spillane, 2005).

There are new social demands that require reform at the school level, these reforms or transformations must be promoted from within each school centre. In this context, a strong direction is basic, whose aptitudes have competences to perform all functions, from a vision of DL. It urges in the Spanish centres a school direction that acts as an engine of change, committed with the whole educational community and whose project is common (García, 2017). Two unfavourable factors must be pointed out for Spain, firstly, exposes the OECD (2008), in Spain the school management is very weak, there is a model of direction very different from the rest of the European countries, with the exception of Portugal. Both countries have built an address with very different characteristics, full of difficulties and unfortunately in the case of Spain, there is no professionalization or leadership. The characteristics of the system itself are transformed into barriers to the exercise of leadership. Secondly, the new Education law (MECD, 2013 and Spanish Organic Law, 2013), further closes the doors to an autonomy of the centres, scarce curricular, pedagogical competencies. Spain is one of the countries where school managers play lower leadership quotas (OECD, 2013b). Spain has a weakened direction, must go to international trends where leadership and an effective direction are key to school improvement (Bolívar, 2015).

The research has shown that the behaviour and attitude of the person assuming the functions of management in the school are a key element that determines the existence, quality and success of processes of change in the institution (Garcia, 2017).

\section{Method}

The research in this communication, is basically to investigate the different profiles characteristic of the principals of the primary schools of Madrid, in relation to the four dimensions of the distributed leadership, with the aim of: Identifying the profiles of the Principals that allow to visualize the dynamics of interaction between the different 
dimensions of the distributed leadership, in relation to the demographical and contextual variables that these directors have.

For the study of the relations between the variables or dimensions of DL, the analysis of main components (ACP) was applied, which reduces a large number of operative indicators in a lower number of conceptual variables (Pérez and Medrano, 2014, p. 72). This method can verify continuous variables as dichotomous and is part of the set of techniques included in the

analysis of data, as mentioned in the approach of the French current or geometrical data analysis (Le Roux \& Rouanet, 2010). It allows the choice of active and illustrative or supplementary variables. The first ones are those that intervene in the calculations of diagonalization of the matrix whereas the second ones are projected in the factorial space constructed from the active variables. The statistical processing of this study was carried out with the program SPAD (Systéme Portable pour l'Analyse des Données) in its version 4.51 (Lebart et al., 2000), because it is the only software that allows the selection of active and illustrative variables.

\subsection{Sample}

The population is the group of Directors of primary education centres of the Autonomous Community of Madrid (ACM)1, corresponding to 244 public primary schools and 277 private, according to the database of the cam (MECD, 2018). The exhibition was made up of 23 primary school principals from the autonomous community of Madrid. Incorporated public, private and concerted centres, located in the different geographical areas according to the direction of territorial area of Madrid (central Madrid, north, south and east). This type of sampling was chosen in the attention that obtaining the collected information depended exclusively on the authorization of the managers to implement the instrument. The composition of the schools is given by 7 concerted (31\%) and 16 public (69\%). The female Gender 13 directors (57\%) and 23 men (43\%). The age of the participants preserves the proportionality of the composition of the directors (as), there is a predominance between the $52-58$ years $(35 \%)$, however, it is significant the existence of directors with ages between $32-51$ years. $17 \%$ is between $32-51$ years respectively. $35 \%$ corresponds to 52 and 58 years and $13 \%$ to $59-64$ years. Within the research the experience of the directors is relevant. Most of the managers are $30 \%$ of their ages between 13 and 18 years of experience. $13 \%$ have between 19-24 years of experience; 25-30 years correspond to 22\%; 31-37 years are $26 \%$ and only $9 \%$ corresponds to $38-43$ years. Most of the executives agreed to their positions on the opposition route, which is $44 \% .30 \%$ got their charges for management projects. Finally, $26 \%$ did it for the contest.

1 The ACM is one of the seventeen autonomous communities of Spain. It is located in the centre of the Iberian Peninsula, and of the Castilian Central Plateau. Madrid is the capital which is also the capital of the country. It was created for administrative and political reasons, as the seat of the capital of Spain (Kapitsinis., et al 2010).

\subsection{Research Design}

The design is field, since the data that was used were collected directly from the reality and 
the pertinent information for the development of this research was obtained from living or direct sources in its natural environment. In this communication, some of the results obtained in the quantitative and descriptive research are exposed, based on the questionnaire "The distributed leadership of the school management" an ad hoc instrument, realizes the results obtained for one of the Four dimensions: "PDL" (12 items).

\subsection{Study Data Collection Tools and Techniques}

The validation by experts allowed to evaluate the correspondence of the dimensions included in the scale with its conceptual definition, and with the items. In this way it was attempted to ensure that the scale items were relevant to the concept of distributed leadership. Six experts were used for validation. The selection was done in response to its experience in methodological aspects, educational research and knowledge on the theme of leadership. For the calculation of the reliability $\alpha$-Cronbach was used and the results are shown below (Table 1).

Table 1. Calculation of Cronbach Alpha Reliability Statisticians

\begin{tabular}{ll}
\hline Cronbach alpha & Elements \\
\hline .9333 & 45 \\
\hline
\end{tabular}

Note: Own elaboration

The value of 0.933 certifies that the total instrument is highly reliable for 45 elements. To ensure that each of the dimensions of the test was equally reliable, the $\alpha$-Cronbach was also applied to each of them. The PDL dimension has a reliability of 0.759 and consists of 7 elements. Then the shared decisions dimension presents a reliability value of 0.787 with 11 elements. The mission, vision and shared goals has a value of 0.839 and 11 elements. Finally, the professional development, complexity of the task and incentives has a 0.754 of reliability for 13 elements (Table 2).

Table 2. Cronbach Alpha of the Four Dimensions of Distributed Leadership

\begin{tabular}{lll}
\hline Dimensions & Cronbach Alpha & Elements \\
\hline PDL & 0.759 & 7 \\
Sharing decision & 0.787 & 11 \\
The mission, vision and shared goals & 0.839 & 11 \\
The professional development, complexity of the task and & 0.754 & 13 \\
incentives & & \\
Total & & 45 \\
\hline
\end{tabular}

Note: Own elaboration.

\subsection{Variables Considered}

The variable to describe is DL, it focuses on the interaction between the employees, in which 
it recognizes the work of all the individuals by contributing in the practice in the decision making and in the delegation of responsibilities and authority, even if they are not formally defined as leaders, and it is fundamental in the configuration of the system and of the organization because the redesign of the Organization requires a process of decision making shared (Garcia, 2017).

\subsubsection{Dimensions of Leadership}

The dimensions of distributed leadership. Distributed leadership consists of four dimensions, which are listed below:

Shared vision, mission and goals: it is the aspect of distributed leadership that implies that everyone is committed to the shared goals of the institution with a sense of purpose or long-term vision; It is considered that the school has a set of shared values that guide the efforts, promote confidence and commitment among teachers, managers, administrative staff and educational community. There is a strong commitment to the shared goals of the Organization as a whole and the philosophy of the school and a long-term vision of the college are shared with all staff; The school is sensitive to the needs of the students, parents and community, and it generates support in helping, establishing and communicating the group clearly the course of the institution.

Distributed Leadership Practices: there is a delegation of work, and the Director assumes that the sum of the shares represents more than the parties, because the participative work translates into a learning for the organization. The management considers that the most participatory forms of leadership work best and allow access to the collective knowledge of the organization, as well as to manage democratic processes to use the conflicts productively, which requires to arrange and regularize informal relations to improve existing agreements.

Professional development of teachers, complexity of the task: relates to reflection and dialogue to delegate, Orient, leverage and improve the skills and knowledge of all teachers, and create a positive and effective common culture, as well as Provide a consistent and coherent school curriculum between subjects and levels, as well as a system of goals and incentives. Leadership actions contribute to the development of people in order to advance productively in the institution. Management and leadership are practiced as a reflection of the school's culture, ethics and traditions. In addition, it includes the planning of the professional development of the team, through assistance to seminars, courses, workshops, etc., and supports the allocation of the necessary resources to promote the efforts of school improvement.

Shared decisions of the Organization: we work on the basis of cooperation rather than competition, to promote productivity within the school, with a "holistic" vision of the organization and with flexible professional practices. The members of the organization discuss and help each other in a spontaneous way to solve any problem, through agreements to modify certain organizational structures, and through parental involvement, in order to make decisions about teaching and learning their children in school. 


\section{Ml Macrothink}

\subsubsection{Demographic and Context Variables}

In addition to distributed leadership, some demographic and context variables were also incorporated. These are the conditions under which the event is manifested to describe, then each one of them is defined. The variable to describe is distributed leadership, which is defined below:

- Age: Defined as the number of years elapsed from birth to the time of investigation.

- Experience as a manager: it is defined as the number of years elapsed since its incorporation to the position of Director (a), until the time of the investigation.

- Academic experience: Refers to the number of years elapsed since its inception in work as teachers until the time of the investigation.

- Experience in the position of executive: refers to the number of years as a director until the time of the investigation.

- Type of entry to the position of Director: refers to the way in which managers enter the Spanish educational system according to the educational law. In Madrid they are by regulation and can be:

- Educational project of the management: it is one of the forms established to participate in the selection of the schools in the incorporation to the directors (as) in the offices (cases Studied in Madrid).

- Election by the school board and faculty of Professors: corresponds to the appointment of the principal.

- Direct designation by the administration: assignment chosen by the school board and other members of the school.

- Character of the institution: it has to do with the type of school. The Spanish educational system includes three types of primary schools: public, private and concerted.

- Public schools: They are lay centres, financed and managed by the Government with the help of the local administrations of each zone. The majority of these centres have all levels of basic and compulsory education (children, primary, secondary and baccalaureate, although some centres delegate the higher cycles in public institutes).

- Concerted schools: They are private-nature centres (not created by the administration) but subsidized largely by the Central administration. They have freedom of management with an adaptation to certain conditions established by the government as limit of students by class, dates, admissions, etc. They finance part of their offer with subsidies and another with parental payments.

- Private schools: These are private-nature centres (not created by the administration). They have freedom of management with an adaptation to certain conditions established by the government as limit of students by class, dates, admissions, etc. They finance their offer with parents ' payments. 
- Gender of Directors: it has to do with male or female sex.

- Tendency of the enrolment of the schools of Madrid: measures the behaviour of admission and withdrawal of students compared with previous years.

- Dropout of students from the Madrid colleges: measures the population of students who retire from a school to migrate to another.

\subsubsection{Data Analysis Procedures and Techniques}

The law of the elbow has been used, which is based on the following: the inertia explained by each successive axis must be decreasing. If you represent the histogram of your own values with the numbers of the axes in ordinates and the percentages of inertia in Abscissas, you can remove the axes whose order number is posterior to the "elbow" that occurs in the curve. So, this case, we're left with the first three axes. In the histogram of eigenvalues, it can be observed that the first factor explains $79.55 \%$ of the variance. It is the longest factor and suggests that there is a high correlation between all the dimensions of DL. It follows a second factor that collects $11.72 \%$ of the variance. Factor Three (3) collects $5.80 \%$ of the variance. These three factors, together, account for $97.07 \%$ of the data variance. In this histogram it is appreciated that the first factor concentrates the most information and in it all the variables have a high weight. It could be said that this first factor is a general ordering factor that presents a hierarchy of the dimensions of the DL, from which it contributes the most to the least it contributes. In this factor the four dimensions are highly correlated and have a high contribution, which indicates that the distributed leadership can indeed be considered as a four dimensional global variable.

\section{Study Results}

Below are analysed the two planes product of the combinations of the factors. This analysis corresponds to the development of the objective: to identify the profiles of the directors (as) that allow to visualize the dynamics of interaction between the different dimensions of the distributed leadership, in relation with the demographic variables and of Context of the primary education schools in Madrid.

\subsection{Analysis of the Plane Formed by Factors 1 and 2}

When ordering factors 1 and 2 (Figure 1) in a Cartesian plane it is possible to see how the dimensions are combined to generate certain DL profiles and how context variables participate in that characterization. One explains each of the quadrants of the plane formed by the factors 1 and 2, the quadrants are four, two at the top (upper right quadrant and upper left quadrant) and two at the bottom (right lower quadrant and lower quadrant left).

The arrows should be interpreted as direction of growth of the variables in the factorial space. The analysis will be done following the clockwise direction. In Figure 1 A first aspect that draws attention is that the three continuous variables of context: experience as a manager (EXPDR); Academic experience (EXP) and age (Ed). They correlate negatively with some of 


\section{Macrothink}

the dimensions of DL, because they move almost in the same vector but in opposite directions. Likewise, academic experience (EXP) correlates negative with professional development, task complexity and incentives, evaluation and staff Development (PTEDP). This means that as directors have more experience or are older in academia, they are less interested in promoting the development of their staff, training and evaluation. It also correlates negative with distributed leadership practices (PTPDL), that is, as they have more experience as managers are more reluctant to share their leadership, promote teamwork and delegate power.

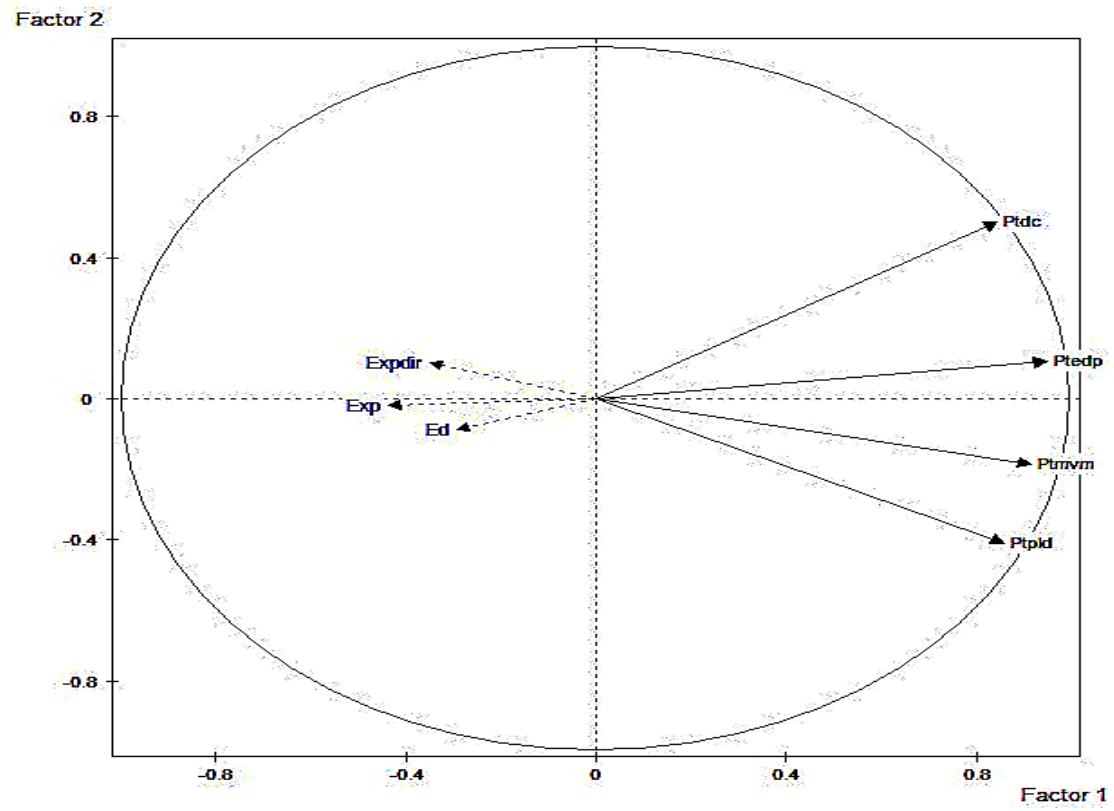

\begin{tabular}{llll}
\hline Principal Experience & Expdr & Sharing decision & Ptdc \\
Academic Experience & Exp & Professional development & Ptedp \\
Age & Ed & Mission, vision and shared goals & Ptmvm \\
& & Leadership Practice & Ptpdl \\
\hline
\end{tabular}

Figure 1. Quadrant Representation Consisting of Factors 1 and 2, with the Illustrative Variables Continued. Own Elaboration.

On the other hand, the experience as managers (EXPDR) correlates negative with the dimension mission, vision and shared goals (PTMVM), means that managers with greater experience in the position are those who are less concerned with working towards a shared vision and a firm commitment to the mission and institutional goals. Age (Ed) seems to correlate negative with the shared decisions (PTDC) dimension, which results in greater age of managers, less interest in fostering cooperation and integrated work in the organization. Younger directors seem to be the most inclined for shared decisions. In order to make a larger analysis, the four quadrants of factors 1 and 2 are presented with the respective nominal illustrative variables Figure 2. 


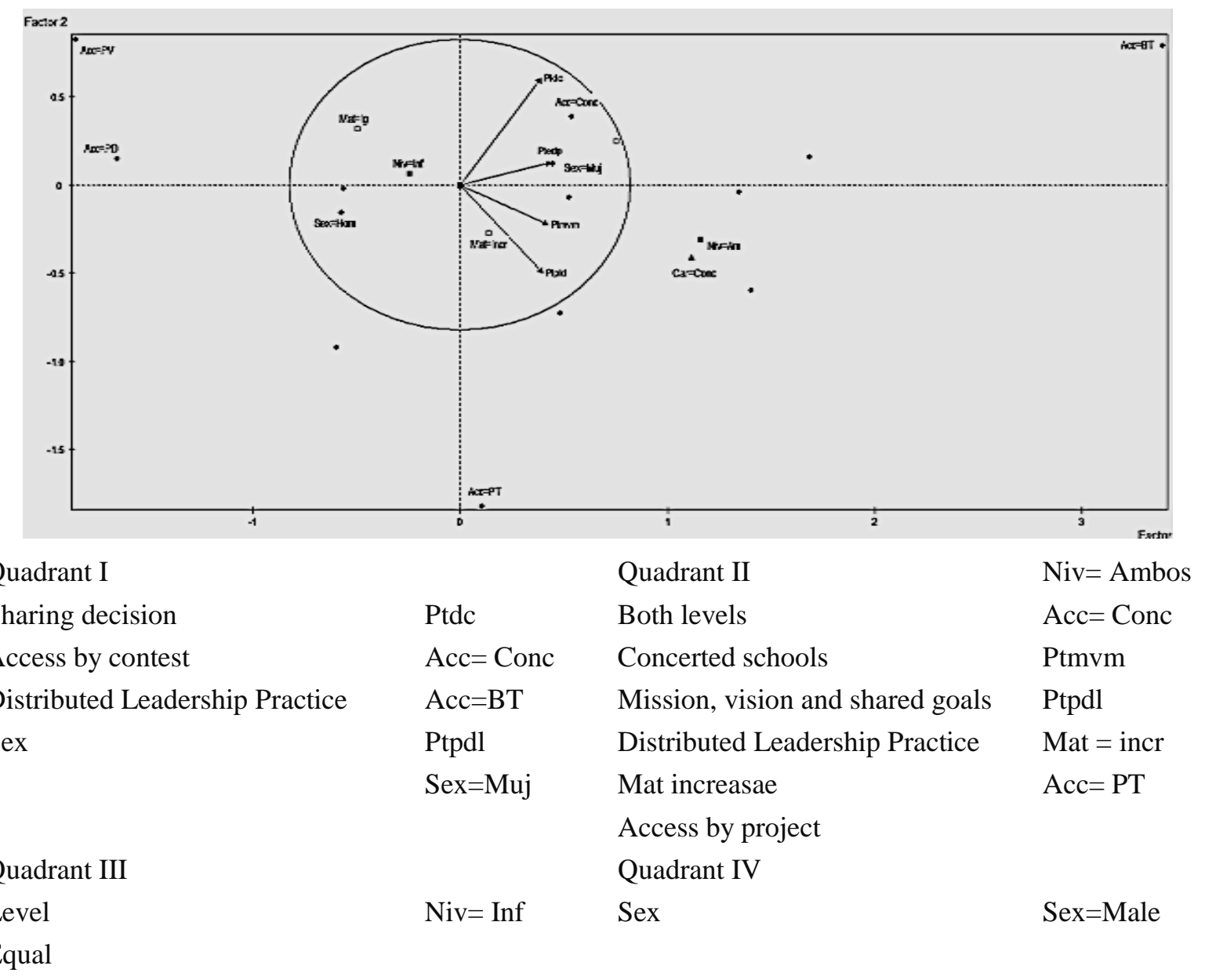

Access by project

$\mathrm{Acc}=\mathrm{PT}$

Access by vigor

Acc $=$

Figure 2. Quadrants Formed by Factors 1 and 2, with Nominal Illustrative Variables. Own Elaboration

In the right upper quadrant (I), managers who emphasize the dimensions of shared decisions and professional development are located, complexity of the task and incentives, who also accessed the position through the job market and most are women. They are managers who promote cooperation, teamwork and the distribution of tasks, but do not encourage the emergence of new leaders. The professional development of the personnel in this case, is probably more focused on the competencies for the development of the tasks that correspond to each one. They are also junior managers, less academic experience and less experience in the office. The access types that predominate in this quadrant are by contest $(\mathrm{acc}=\mathrm{Conc})$ and work bag $(\mathrm{acc}=\mathrm{Bt})$. In Figure 2 there seems to be a slight predominant tendency for these managers to be women, but the values were not significant.

In the right lower quadrant (II) Figure 2, the directors are located who work more the 
practical dimension of distributed leadership, accompanied by the dimension mission, vision and shared goals. Here are the schools of a concerted nature that have both levels and whose enrolment has increased. On the other hand, in this quadrant sex has no weight.

The directors who are located in this sector of the plane exert a form of leadership characterized by an effort to emerge other leaders within the institution, the intention to delegate their work as leaders. This attitude is accompanied by the promotion of vision, mission and institutional goals in order to generate commitment to these aspects of the Organization. The access by project of work correlates negatively with the factor 2 , but positively with "mission, vision and shared goals and with distributed leadership practices, that is to say that the managers (as) of the schools that are in the lower quadrant Right are the ones that had the highest scores in those two dimensions.

In the two left quadrants of this plane are the opposite attributes to those examined in the two quadrants of the right side: in the lower left quadrant (III) (Figure 2) are the directors (as) who have rejection towards the dimension's development Professional, task complexity, and incentives, but some may have high scores on distributed leadership practices and "mission vision and shared goals." In this quadrant are the senior directors. There seems to be a tendency for men to locate in this quadrant, but the values were not significant. The upper left quadrant (IV) brings together directors who have rejection of distributed leadership practices and to work with mission, vision, and shared goals, but some may have some tendency to work with the aspects of Shared decisions and professional development, task complexity and incentives. In this quadrant are the directors of greater experience in the position and their access was by project direction and process in force. The enrolment of the schools in this quadrant remained the same. To achieve a better interpretation of other possible dynamics, it is important to analyse the intersection of factors 2 and 3.

\subsection{Analysis of the Plane Formed by Factors 2 and 3}

After analysing the quadrants of factors 1 and 2 with the respective nominal illustrative variables, we will proceed with the analysis of factors 2 and 3. The following is the distribution of DL dimensions in the plane formed by factors 2 and 3 (Figure 3).

In the upper right quadrant (I) of the plane formed by factors 2 and 3 are located the Directors (as) that focus on the professional development, complexity of the task and incentives, i.e., are concerned with improving the skills and knowledge of all teachers of the centre, they know the capacities of their colleagues, they plan the professional development of the professors and the team by means of assistance to seminars, courses, workshops and they make sure to have the budget for it. Despite this, they do not make distributed leadership practices, as they prefer not to enhance the leadership of other members of the organization or delegate their work as leaders. These managers are the youngest. With respect to the variables of context, in this quadrant there are no particular characteristics as to the type of access of the principal (a), character of the institution, nor academic level. They are only characterized because the tuition remained the same.

The second group corresponds to the right lower quadrant (II), involving the most 


\section{Macrothink}

experienced executives, who focus on shared decisions, but do not necessarily share their leadership; They encourage cooperation in the accomplishment of tasks, promote communication, group integration and promote the joint work of the members of the Organization., but do not necessarily share their position as leaders and reject work with Mission, Vision and shared goals, so this can lead to disarticulated work or that is not in line with the guidelines of the institution. The integration they promote is group, among people, but it is not an institutional integration. This quadrant corresponds to schools of a public nature, where their directors entered by the labour exchange or by process in force, and the tuition decreased.

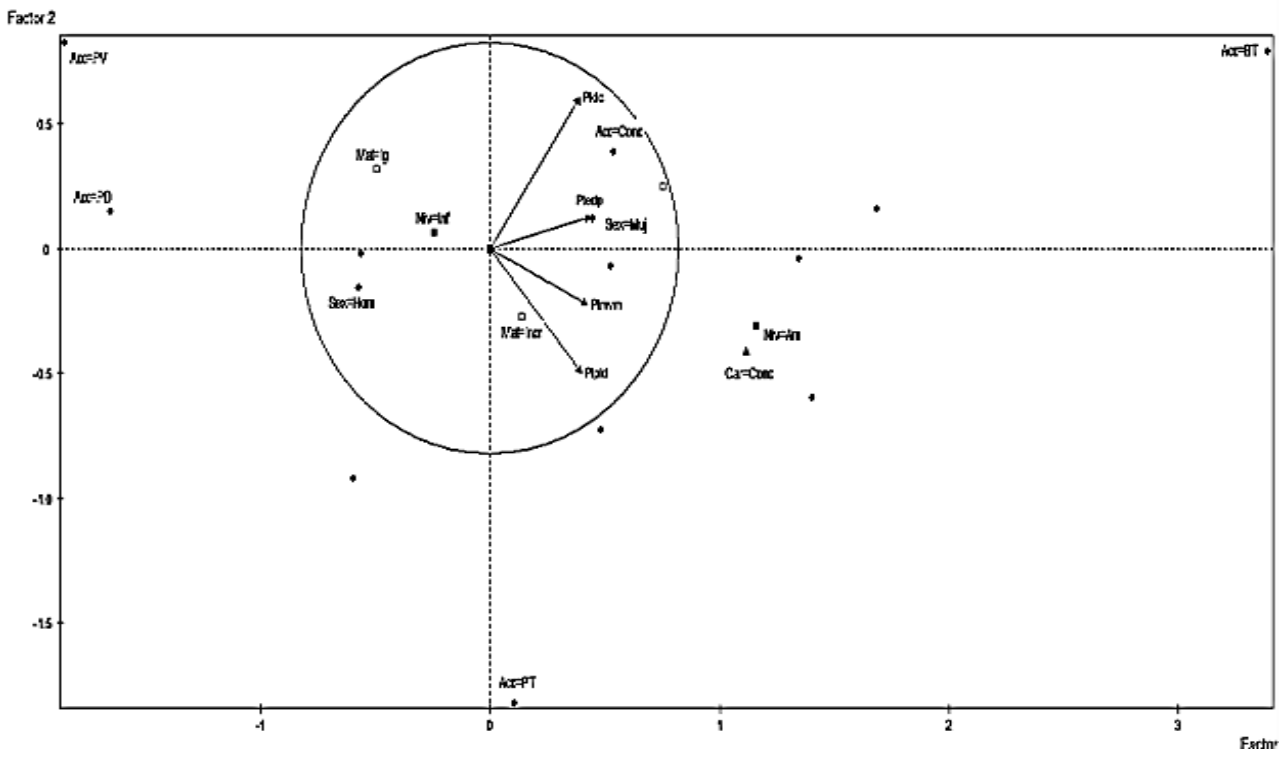

Cuadrante I

Decisiones compartidas

Acceso al cargo por concurso

Acceso al cargo por bolsa

Prácticas de liderazgo distribuido
Ptdc

Acc $=$ Conc

$\mathrm{Acc}=\mathrm{BT}$

Ptpdl

Sex=Muj

\section{Cuadrante II}

Ambos niveles

Escuelas concertadas

Visión. Misión y metas compartidas

$\mathrm{Niv}=\mathrm{Am}$

Acc $=$ Conc

Ptmvm

Prácticas de liderazgo distribuido

Ptpdl

Matricula incremento

Mat=incr

Acc eso por Proyecto de trabajo

Cuadrante III

Nivel

Niv $=$ Inf

Matricula igual

Mat $=I g$

Acceso por Proyecto de trabajo

$\mathrm{Acc}=\mathrm{PD}$

Acceso proyecto en vigor

$\mathrm{Acc}=\mathrm{PV}$

Sexo

$\mathrm{Sex}=$ Hombre

Figure 3. Quadrant Representation by Factors 2 and 3, with the Illustrative Variables Continued. Own elaboration 
In the lower left quadrant (III) are the directors who perform distributed leadership practices and encourage the leadership of other members, are greater in age and pedagogical experience, but do not enhance personal development, training, nor the evaluation. In this quadrant tend to be the schools where tuition increased, but there are no particular conditions related to the other nominal illustrative variables.

In the upper left quadrant (IV) are those who focus on the mission, vision and shared goals, but oppose the distribution of tasks. This unity of vision, mission and goals is more an agreement with institutional ideals, but they do not necessarily translate into collaborative work. The schools that are associated with this quadrant are those of a concerted nature and with both levels. The directors ' access is by proposal of ownership. Finally, this objective ends with the determination of eight of the profiles shown in the directors of the schools of Madrid subject to study.

\section{Discussion}

The identification of the profiles of the directors and their interrelationships provide conceptual tools, which apply to the schools define the management and practices of the DL, by the directors. The fact that this analysis corresponds to the development of the objective raised in relation to the synergy resulting from the four dimensions of the DL, and in relation to the demographic and context variables defined, should be highlighted for schools of Madrid.

It is clearly seen that in this study the administrative theory, such as research in improving school effectiveness (Maureira et al., 2014; Spillane, 2017), have been specifying the capacities of influence, based on the DL, must be retrained in the active participation of other actors of the organization, both in formal and informal positions.

The complexity of the formative work cannot be underestimated, which requires the identification and deployment of all DL's capacities, in particular that of the directors. These considerations added to the other school actors have established the origin of the DL, but should be taken into account in this discussion, that there are several difficulties of conceptualization and implementation for the production of knowledge that possesses the DL.

Indeed, to deepen the descriptive analysis simultaneously of the characteristics studied, a principal component analysis (PCA) was applied achieving to identify for example (Greenacre, 2017), the managers who work more the practical dimension of DL (PTPDL), accompanied by the dimension mission, vision and shared goals (MVMC), are specifically the schools of a character, in this quadrant the genre has no weight.

It is observed that there are managers, who exercise a form of leadership characterized by an effort, to emerge other leaders within the institution, whose intention is to delegate their work as distributed leaders. This attitude is accompanied by the promotion of the (PTMVM), in order to generate commitment with these aspects of the Organization.

As a characteristic of the access by project of work, the same correlates negatively with the 
factor 2, but positively with (PTMVM), and with (PTPDL), that is to say that the managers (as) of the schools that are in the lower right quadrant are those that Higher scores had in those two dimensions.

As negative factors, managers ' relationships that have a rejection of the dimensions of professional development, task complexity and incentives are observed, but some may have high scores in distributed leadership practices and ' mission Vision and shared goals ". In this quadrant are the senior directors. There seems to be a tendency for men to locate in this quadrant, but the values were not significant. In this regard, it should be mentioned the point related to the profession which is aging. The average school leader in OECD countries is 51 years old and will retire within the next five to ten years. In addition to improving the quality of today's school leadership, it is imperative to develop clear plans for future leadership and effective leadership succession processes (OECD, 2008, 2013b).

In other factors there are directors who have rejection of distributed leadership practices and to work with shared mission, vision, and goals, but some may have a tendency to work with shared-decision aspects and Professional development, complexity of the task (OECD, 2008, 2013a).

Thus, empirical evidence was found to justify the recommendations for strengthening DL, as defined by improving school leadership increases the quality and sustainability of school leadership. There are four areas of action that, undertaken together, can improve the practice of leadership: (RE) define the responsibilities of school leadership. Distribution of school leadership. Developing skills for effective school leadership and making school leadership an attractive profession (Spillane \& Diamond, 2007).

Finally, by way of reflection, with respect to the policies and/or programs for the formation of school executives, it becomes a priority to strengthen school organizational capacities, passing of formative designs individualistic and theorists of executives to others, more collegiate and practical in integrating formal and informal leaders, considering key stakeholders in the school community (Bolívar, 2014 and Ritacco \& Bolívar, 2018). Also as Bolívar (2014) explains: If schools are to meet the needs of students and achieve educational success, to achieve both goals simultaneously, they should provide opportunities for Principals to innovate, share experiences and learn together.

One of the most important ideas of this article is to build innovations theories and practices to improve the capacity of the school through DL. Additionally, it combines in a design the description of the Elementary schools of Madrid, showing the different profiles in their levels of educational management as delegation and sharing of the different level.

\section{Conclusion}

It presents the analysis of the factors in which eight profiles of directors (as) are shown, which are described below. 


\subsection{The Product Result of Factors 1 and 2 Gives Four Types of Profiles}

Formal leader. Upper left quadrant. They avoid delegating power, they are not interested in fostering a vision and institutional mission, but it can focus on fulfilling tasks does not generate synergy. They are directors with a lot of experience in the position and their access was by project of direction and process in force. Their schools keep the same tuition. (Schools 4, 10, 22, 18 and 15)

Innovative leader. Upper right quadrant. Young directors, predominantly women with little work experience, who obtained the competition fee or by job exchange. These managers encourage delegation of tasks, promote cooperation and integrated work in the organization, but do not encourage the emergence of new leaders. They are interested in motivating the professional development of their teaching staff, providing incentives and emphasizing the complexity of the tasks. But it can give little importance to the mission, vision and institutional goals (schools 9, 1, 12, 5 and 21).

Bureaucrat leader. Lower left quadrant. Directors who do not value the professional development of their teachers, prefer simple tasks and do not provide incentives, but some may have high scores in distributed leadership practices. They assign charges, but without preparing their staff, and focus on the mission, vision and shared goals. In this quadrant are the senior directors, probably men (schools 7, 23 and 11).

Organizational poietic leader. Lower right quadrant. It strives for other leaders to emerge within the institution, intends to delegate their work as leaders. This attitude is accompanied

by the promotion of vision, mission and institutional goals in order to generate commitment to these aspects of the Organization. They are in schools that have both levels of study, have a concerted character and whose enrolment increased. (Schools 3, 8, 19, 17 and 6).

\subsection{The Result of Factors 2 and 3}

The product result of factors 2 and 3 gives four types of profiles. The profiles of the leader's product of factors 2 and 3 are presented below.

Institutional leader. Upper left quadrant. Directors who focus on the mission, vision and shared goals, but oppose the distribution of tasks. This unity of vision, mission and goals is more like an agreement with institutional ideals, but they do not necessarily translate. In collaborative work. They are in schools of a concerted nature and with both levels. Your access is by proposal of ownership.

Training leader. Upper right quadrant. They focus on the professional development, complexity of the task and incentives, that is, they are concerned with improving the skills and knowledge of all the teachers of the centre, they know the capacities of their colleagues, they plan the professional development of the teachers And the team by attending seminars, courses, workshops, and making sure they have the budget for it, but do not do distributed leadership practices in the sense that they prefer not to enhance the leadership of other members of the organization or delegate their I work as leaders. Are the youngest. 
Empowering leader (dispersed leadership). Lower left quadrant. Directors who conduct distributed leadership practices and encourage the leadership of other members, delegate power and authority, are greater in age and pedagogical experience, but do not enhance personal development, training, or evaluation. They delegate power but not knowledge. They are in schools where tuition has increased.

Leading communication promoter. (Collaborative leadership). Lower right quadrant. The most experienced managers, who focus on shared decisions, but do not necessarily share their leadership. They encourage cooperation in the accomplishment of tasks, foster communication, group integration and promote the joint work of the members of the organization, but do not necessarily share their position as leaders and reject work with mission, vision and shared goals. This can lead to disjointed work or that is not in line with the institution's guidelines. The integration they promote is group, among people, but it is not an institutional integration. They are in schools of a public nature, where their directors entered by the labour exchange or by process in force, and the tuition decreased.

\section{References}

Bennett, N., Harvey, J. A., Wise, C., \& Woods, P. A. (2003). Desk study review of distributed leadership, Nottingham, UK: National College for School Leadership. [Google Scholar]

Bolden, R. (2011). Distributed Leadership in Organizations: A Review of Theory and Research. International Journal of Management Reviews, 13(3), 251-269. http://dx.doi.org/10.1111/j.1468-2370.2011.00306.x

Bolívar, A. (2014). Building school capacity: Shared leadership and professional learning communities. A research proposal. International Journal of Educational Leadership and Management, 2(2),147-175. http://dx.doi.org/10.4471/ijelm.2014.15

Bolívar, A. (2015). The comprehensive school in Spain: A review of its development cycle and crises. European Educational Research Journal, 14(3-4), 347-363. https://doi.org/10.1177/1474904115592496

Day C. (2017). School Leadership as an Influence on Teacher Quality. In: Zhu X., Goodwin A., Zhang H. (eds.), Quality of Teacher Education and Learning. New Frontiers of Educational Research. Singapore https://doi.org/10.1007/978-981-10-3549-4_7

Spanish Organic Law. (2013). Organic Law 8/2013, of December 9, for the improvement of educational quality. State official newsletter. Retrieved from http://www.spanishreforms.com/documents/10180/12868/Organic+Law+8-2013+on+Ed ucation+\%281egal+text+in+Spanish\%29.pdf/7d09965f-0071-4d8c-b361-d69e1a7e3db9

Elmore, R. (2008). Accountable leadership. The Educational Forum, 69(2), 134-142. https://doi.org/10.1080/00131720508984677

García, I. (2017). Educational Innovation from Distributed Leadership: Case Study Spanish 
Public School. Journal of Educational Psychology-Propósitos y Representaciones, 5(1), 152. http://dx.doi.org/10.20511/pyr2017.v5n1.152

Greenacre, M. (2017). Correspondence analysis in practice. Portland: CRC Press.

Gronn, P. (2002). Distributed leadership as a unit of analysis.The Leadership Quartely, 13(4), 423-451. https://doi.org/10.1016/S1048-9843(02)00120-0

Gronn, P. (2008). The future of distributed leadership. Journal of Educational Administration, 46(2), 141-158. https://doi.org/10.1108/09578230810863235

Hargreaves, A. (2002). Sustainability of educational change: The role of social geographies. Journal of educational change, 3(3-4), 189-214. https://doi.org/10.1023/A:1021218711015

Harris, A. (2004). Distributed leadership and school improvement: leading or misleading?. Educational Management Administration \& Leadership, 32(1), 1124.https://doi.org/10.1177/1741143204039297

Harris, A. (2013). Distributed school leadership: Developing tomorrow's leaders. New York: Routledge.

Harris, A. (2014). Distributed Leadership Matters: Perspectives, Practicalities, and Potential. Thousand Oaks CA.: Corwin.

Hulpia, H., Devos, G., \& Van Keer, H. (2009). The influence of distributed leadership on teachers' organizational commitment: A multilevel approach. The Journal of Educational Research, 103(1), 40-52. https://doi.org/10.1080/00220670903231201

Kapitsinis, N., Karampini, E., Bakratsa, F., \& Nikolakopoulou, X. (2010). Regional inequalities and localist movements: relational complexities beyond linear determination, 50th Congress of the European Regional Science Association: "Sustainable Regional Growth and Development in the Creative Knowledge Economy", 19-23 August 2010, Jönköping, Sweden Retrieved from https://www.econstor.eu/bitstream/10419/118980/1/ERSA2010_0735.pdf

Knapp, M., Honig, M., Plecki, M., Portin, B., \& Copland, M. (2014). Learning-focused leadership in action: Improving instruction in schools and districts. New York and London: Routledge.

Leithwood, K. (2009). How to Lead Our Schools: Contributions from research. Santiago, Chile: Chile Foundation.

Leithwood, K., Mascall, B., Strauss, T., Sacks, R., Memon, N., \& Yaskina, G. (2007). Distributing Leadership to Make Schools Smarter: Taking the Ego Out of the System. $\begin{array}{llll}\text { Leadership and Policy in } & \text { Schools, } & \text { 37-67. }\end{array}$ https://doi.org/10.1080/15700760601091267

Lebart, L., Morineau, A., \& Piron, M. (2000). Statistique exploratoire multidimensionnelle. Paris: Dunod. http://www.documentation.ird.fr/hor/fdi:010029478 
Le Roux, B., \& Rouanet, H. (2010). Multiple correspondence analysis. Quantitative applications in the social sciences. A Sage University Paper Series on Quantitative Applications in the Social Sciences,07- 163. Thousand Oaks, CA: Sage.

Maureira, O., Moforte, C., \& González, G. (2014). More distributed leadership and less leadership: New perspectives to characterize processes of influence in schools. Educational profiles, 36(146),134-153. https://doi.org/10.1016/S0185-2698(14)70132-1

MECD (Ministerio de Educación, Cultura y Deporte). (Ministry of Education, Culture and Sport). http://www.mecd.gob.es/mecd/portada-mecd.html

MECD (2013). Ley Orgánica para la Mejora de la Calidad Educativa, http://www.boe.es/diario_boe/txt.php?id=BOE-A2013-12886

MECD (2018). Datos y Cifras: Curso Escolar 2017/2018, https://www.mecd.gob.es/servicios-al-ciudadano-mecd/dms/mecd/servicios-al-ciudadan o-mecd/estadisticas/educacion/indicadores-publicaciones-sintesis/datos-cifras/Datosycifr as1718esp.pdf

Organization for Economic Cooperation and Development (OECD) (2008). Education and Training Policy, Improving School Leadership, Volume 1: Policy and Practice, Summary in English. Paris: OECD. https://www.oecd.org/edu/school/44374889.pdf

Organization for Economic Cooperation and Development (OECD) (2013a), Teaching and Learning International Survey (TALIS). Retrieved from http://stats.oecd.org/index.aspx?datasetcode=talis_2013\%20

Organization for Economic Cooperation and Development (OECD) (2013b), Leadership for 21st Century Learning, OECD Publishing, Paris. http://dx.doi.org/10.1787/9789264205406-en

Pérez, E., \& Medrano, L. (2014). Exploratory factor analysis: conceptual and methodological bases. Argentine Journal of Behavioral Sciences, 2(1), 71-85. http://www.redalyc.org/pdf/3334/333432764009.pdf

Ritacco, M., \& Bolívar, A. (2018). School principals in Spain: an unstable identity. International Journal of Educational Leadership Manager (JELM), http://doi.org/10.17853/ijelm.2018.2110

Shatzer, R., Caldarella, P., Hallam, P., \& Brown, B. (2014). Comparing the effects of instructional and transformational leadership on student achievement: Implications for practice. Educational Management Administration \& Leadership, 42(4), 445-459. https://doi.org/10.1177/1741143213502192

Spillane, P. (2005) Distributed Leadership. The Educational Forum, 69(2), 143-150. http://dx.doi.org/10.1080/00131720508984678

Spillane, J. (2017). Leadership and Learning: Conceptualizing Relations Between School Administrative Practice and Instructional Practice. Societies, 5(2), 277-294. 
http://dx.doi.org/10.3390/soc5020277

Spillane, J., \& Diamond, J. (2007). Distributed Leadership in Practice. New York: Publisher: Teachers College Press.

Woods, P. (2004). Democratic Leadership: Drawing distinctions with distributed leadership. International Journal of Leadership in Education, 7(1), 3-26. http://doi.org/10.1080/1360312032000154522

Woods, P. (2016). Authority, power and distributed leadership. School leadership and management from a distributed perspective, 30(4), 155-160. https://doi.org/10.1177/0892020616665779

\section{Copyright Disclaimer}

Copyright for this article is retained by the author(s), with first publication rights granted to the journal.

This is an open-access article distributed under the terms and conditions of the Creative Commons Attribution license (http://creativecommons.org/licenses/by/3.0/). 